\title{
Aim High or Go Low? Pricing Strategies and Enrollment Effects when the Net Price Elasticity Varies with Need and Ability
}

\author{
Bradley R. Curs \\ Educational Leadership and Policy Analysis \\ University of Missouri \\ Columbia, MO 65211-2190 \\ cursb@missouri.edu \\ 5738822759 \\ Larry D. Singell, Jr. \\ Department of Economics \\ University of Oregon \\ Eugene, OR 97403-1285 \\ lsingell@uoregon.edu \\ 5413464672
}

May 20, 2009

We thank John Cheslock, Steve DesJardins, participants at the 2007 Association for the Study of Higher Education Conference, and three anonymous reviewers for helpful comments on this manuscript. As always, any remaining errors or omissions are the responsibility of the authors. 


\begin{abstract}
Detailed data on individual applicants to a large public university are used to demonstrate that net price responsiveness decreases with need and ability. Enrollment effects are simulated and show a movement towards a high tuition/high aid (low tuition/low aid) policy significantly lowers (raises) tuition revenue with a modest increase (decrease) in the number of aid-eligible students.
\end{abstract}




\section{Aim High or Go Low? Pricing Strategies and Enrollment Effects when the Net Price Elasticity Varies with Need and Ability}

There is a broad national consensus among academics, policy makers, and college administrators that expanding college access to higher education for low-income students is crucial to developing an effective U.S. poverty policy (St. John, 2003). Education policy pundits disagree, however, on whether the most auspicious tuition policy to expand access should follow a high tuition/high aid (HH) model that targets aid or a low tuition/low aid (LL) model that provides universal aid (Mumper, 2003). Specifically, HH proponents contend that on efficiency and equity grounds list tuition should reflect the true cost of college, but that the actual price net of aid should reflect one’s ability to pay (Mortenson, 1993; Schorr, 1988). Conversely, LL advocates argue that college subsidies should be spread more evenly over the student population, because targeted aid programs are unable to attract the necessary long-term popular support and funding (Wilson, 1987; Johnstone, 1997).

Implicit in both the HH and LL models are some form of subsidy motivated by the notion that higher education has a public as well as a private return. Moreover, de facto public policy has led to the real cost of college net of aid increasing for all students (i.e., a higher real tuition, lower real aid) with the rationale that the return to college has increased in recent decades and is primarily private in nature (Card, 1999). Thus, the largely theoretical debate regarding the efficacy of the $\mathrm{HH}$ versus LL pricing strategies on access takes place in the context of an increasing public expectation that students are, and should be, responsible for covering the lion's share of the cost of college (Heller, 2001). 
This paper enters the HH-LL debate in the context of a single large public university, the University of Oregon (UO), by examining the access, quality, and revenue consequences of moving away or towards their explicit LL-mission for (needy) in-state students and implicit HH-policy for (able) out of state students. The UO is an ideal setting to study differences in price responsiveness by need and ability because prior work suggests that net price variation (i.e., tuition minus aid) is largely determined at the institution level and because flagship public institutions tend to attract a deep and heterogeneous pool of freshman applicants (Curs \& Singell, 2002). On the other hand, McMillen, Singell, and Waddell (2007) find that there is a hierarchy of institutions that compete across different applicant pools comprised of students who likely differ in their overall price responsiveness, suggesting significant heterogeneity across institutions in their ability to implement various pricing strategies. It follows that the joint understanding of the access, quality, and revenue effects of the HH and LL models are critical to assessing whether such policies are feasible in the context of the mission and resources of similarly situated flagship public institutions.

While there is a paucity of institutional empirical evidence regarding the impact of the $\mathrm{HH}$ or LL pricing models on access, summaries of enrollment demand studies consistently find that students are relatively unresponsive to changes in the tuition price for a wide variety of institution types (Heller, 1997; Leslie \& Brinkman, 1987). Economic theory generally measures price responsiveness as an elasticity, defined as the percentage change in the number enrollees for a given percentage change in tuition. Thus, an elasticity exceeding the critical value of one implies that enrollment responds relatively more in percentage terms to a tuition change (i.e., students are relatively responsive to a price change), whereas a value less than one implies that enrollment responds relatively less in percentage terms than tuition (i.e., students are relative unresponsive to a price change). 
Tuition revenue, defined as tuition multiplied by enrollment, also directly relates to the elasticity. Specifically, if enrollment is responsive to tuition (i.e., an elastic demand) then revenue will move in an opposite direction to the tuition change, whereas if enrollment is unresponsive to tuition (i.e., an inelastic demand) then revenue will move in the same direction as the tuition change. For example, an increase in tuition would lead to a decrease in tuition revenue if demand is elastic because the enrollment decrease more than offsets the tuition increase, whereas, with inelastic demand, the enrollment decline is relatively small and tuition revenue rises. DesJardins and Bell (2006) describe in further detail how economic theories, and more specifically elasticity, inform enrollment management practices.

For a HH model to truly be effective, institutions must have a group of students whose enrollment demand is relatively inelastic, or unresponsive, such that a university could potentially raise revenue by increasing the tuition revenue generated by those students. This increased revenue could then be used to finance grant programs that would lower the net price to a targeted subgroup of financially needy or academically able students (Rose \& Sorenson, 1992). Thus, the ideal conditions for a HH model to be effective include a large group of potential students that are relatively unresponsive to price changes and a smaller group of desirable students who are relatively responsive to changes in price. Turner (2006) describes the case of The University of Virginia, a public flagship institution, which is expected to have sufficient excess demand of relatively price unresponsive applicants such that a HH policy is expected to yield both increased access to low-income students and increased revenue to the institution.

As needy students may well be financially constrained when it comes to attendance at public institutions in their home state, and highly able students may well have competing merit aid offers, both of these groups of students are likely to be less responsive to the net price at a 
particular university than those students who are less likely to receive either need-based or meritbased aid. It follows that understanding whether there are differences in the net price elasticity by need and ability is critical to assessing the potential enrollment and distributional consequences of a HH or LL pricing strategy. This paper provides some of the first formal evidence that non-aid eligible students are relatively price responsive (i.e., have an elasticity that exceeds one) and that the price responsiveness falls with need and ability at a large public flagship university.

We undertake a two-step process to understand how tuition and financial aid policies influence the composition of UO enrollees by need and ability. First, to determine whether the price responsiveness of applicants differs across need and ability we estimate the net price elasticities for nine different need-ability groups. Second, the elasticity estimates are used to simulate the differential impact on the enrollment of needy and able students of the UO moving towards a HH or LL pricing scenario. The simulations indicate that a movement towards a $\mathrm{HH}$ policy modestly increases the number of aid-eligible students while significantly lowering the nettuition revenue, whereas a movement towards a LL policy yields a modest decrease in the number of aid-eligible students while significantly raising net-tuition revenue. Overall, the findings demonstrate there are revenue and enrollment tradeoffs from adopting either the HH or LL model, each of which has political and financial ramifications.

\section{Background}

Theoretical models of institutional choice posit that students choose an institution that best matches desired characteristics, which include economic and sociological factors (e.g., Cabrera, Burkum, \& La Nasa, 2005; Fuller, Manski, \& Wise, 1982; Jackson, 1978). Sociological factors that are expected to influence institution choice include family background, high-school peers, and a preference for interacting with similar persons. Economic factors expected to influence college 
choice include socio-economic status, price, return on investment, and the consumption value of college. Comprehensive reviews of college choice models can be found in Cabrera and La Nasa (2000), Hossler, Braxton, and Coopersmith (1989), Paulsen (1990), and Perna (2006).

More complex models of college choice hypothesize a multi-stage decision making process for potential students where potential students develop aspirations for higher education in the first stage, identify a set of institutions to apply to in the second stage, and choose the institution to attend in the final stage (Cabrera \& La Nasa, 2000; Hossler, Braxton, \& Coopersmith, 1989; Hossler \& Gallagher, 1987; Paulsen, 1990; Perna, 2006). A handful of multiple stage empirical models show that price responsiveness measures may be understated when an analysis exclusively focuses on the enrollment stage because price can also affect aspirations and application decisions (Abraham \& Clark, 2006; Curs \& Singell, 2002; DesJardins, Ahlburg, \& McCall, 2006). The multi stage sticker shock phenomenon is expected to yield a larger effect on the aspirations, application and college choice behavior of low- and middle-income families where cost is a larger determinant of the college-going decision (Kane, 1999; King, 1999; McPherson \& Schapiro, 1998). Thus, although our paper follows the bulk of the literature that focuses on the enrollment choice stage, the results from the multi-stage empirical research suggest that our single-stage simulations may well offer lower bound enrollment and revenue effects for the HH and LL pricing strategies.

Both the higher education and economics literature consistently find that the decision to enroll and persist in college differs with need and ability (e.g., Dynarksi, 2004; Ehrenberg \& Sherman, 1984; Jackson, 1990; Linsenmeier, Rosen, \& Rouse, 2002; McPherson \& Schapiro, 1991; Singell \& Stone, 2002). For example, Manski and Wise (1983) find that students with high academic ability and those from families with higher parent income and education are more likely to enroll in and complete college. Prior work also finds differences in tuition and financial aid 
responsiveness based on attributes that correlate with need and ability. St. John (1990) shows that college enrollment is positively correlated with grants, loans, and work-study and negatively correlated with tuition, where there is generally a greater price-responsiveness to aid versus tuition changes and the effects of grants (loans) fall (rise) with income.

Student price responsiveness has been estimated using time-series variation in aggregate prices and enrollment for a broad set of universities (Campbell \& Siegel, 1967) or a single institution (Seneca \& Taussig, 1987) and individual variation in the net price and the decision to enroll for a random cross-section of college-age persons (Tierney, 1982) or for applicants to a specific university (Ehrenberg \& Sherman, 1984). Surprisingly, despite substantial variation in both the degree of aggregation and the time period of the data, enrollment elasticity estimates are consistently found to be inelastic for both public and private universities (Doyle \& Cicarelli, 1980; Parker \& Summers, 1993) and for different racial and income groups (Blakemore \& Low, 1983; Wetzel, O’Toole, \& Peterson, 1998). However, a survey of enrollment demand studies by Heller (1997) notes that the majority of work uses data that predate the significant real rise in tuition that began in the early 1980s and suggests that enrollment demand may have become more elastic over the last several decades. Heller's comments are consistent with demand theory which predicts price responsiveness rises as prices become a larger share of the decision maker's budget.

The evidence that the price elasticity differs by easily observed attributes (e.g., need and ability) suggests that institutions have a revenue incentive to charge different net prices to students that do not differ in their cost of instruction (i.e., price discrimination). For example, several former Secretaries of Education, beginning prominently with William Bennett, expressed concern that universities capture federal aid through tuition increases (Bennett, 1987). McPherson and Shapiro (1991), Turner (1998), Long (2004), and Singell and Stone (2007) all find evidence that 
tuition and other price levels rise, for at least some segments of the higher education market, with the increased public provision of financial aid. These findings support theoretical work that demonstrate circumstances when it is in an institution's interest to offer discounts or internal scholarships to maximize the revenue by exploiting elasticity differences between different types of students (Epple, Romano, \& Sieg, 2002; Kolpin \& Stater, 2006; Rothschild \& White, 1995).

The policy effectiveness of the HH and LL models also rests on whether group differences in enrollment elasticities can be exploited to achieve enrollment management objectives. For example, Rose and Sorensen (1992) examine the HH model assertion that universities can expand access by raising tuition to non-needy students in order to fund generous financial aid packages for needy students. Using cross-sectional data for tuition and aid from 502 private universities, they find that high tuition institutions offer more, but insufficient, aid to offset the higher list price such that the price net of aid increases under an $\mathrm{HH}$ policy. This paper explicitly examines whether the price responsiveness differences across need and ability groups of students can limit the enrollment management and revenue objectives of the $\mathrm{HH}$ and LL models.

Empirical Approach

\section{Empirical Model}

A college choice framework is developed to examine how applicants to an institution respond to tuition and aid policies. Specifically, UO applicants are modeled as choosing to enroll or not, where applicants who do not enroll may select a number of alternatives including enrolling at a competing institution or entering the labor market. Given this framework, a random utility approach is adopted where applicant $i$ selects the UO over competing alternatives when this choice provides the student the greatest utility among all possible choices. The specific utility level of applicant $i$ enrolling at institution $j$ is not observed, but the decision of applicant $i$ to enroll at the 
UO is observed if and only if the utility of enrolling at the UO exceeds the utility of the next best alternative.

Following this framework, the decision to enroll at the UO can be modeled as the linear index function:

[1] $E_{i}=\alpha P_{i}+\beta^{\prime} X_{i}+\varepsilon_{i}$, where $E_{i}=\left\{\begin{array}{l}1 \text { if enrolled } \\ 0 \text { if not }\end{array}\right.$

where the dependent variable $\left(E_{i}\right)$ is a binary variable that equals 1 if an applicant enrolls at the UO and 0 if not. The evaluation of the utility maximizing choice of applicant $i$ is a function of the net price of the UO $\left(P_{i}\right)$, personal attributes $\left(X_{i}\right)$ and a normally distributed disturbance term $\left(\varepsilon_{i}\right)$. The random utility approach is commonly used in economics and provides a basis for estimating equation [1] using a probit model of the discrete choice to enroll or not at the UO based upon the aforementioned controls (Curs \& Singell, 2002; DesJardins, Ahlburg, \& McCall, 2006). The Net Price Measure

The probability of enrolling at the UO depends directly on the net price parameter, $\alpha$, which provides a measure of the enrollment response to the net price conditioned on student attributes. Because the UO is a destination campus with relatively few commuter students, the net price is defined as the tuition plus room and board minus scholarships and grants. Loans are included as a separate control variable and are not used in the net price calculations because they must be repaid and, although including a subsidy in some instances, do not lower college costs dollar for dollar. Likewise, work-study is included separately from the net price measure as the work requirement imposes a separate cost on the student. The net price variable varies across time due to changes in tuition charges and aid generosity and varies across individuals due to difference in financial aid packages. 
With respect to price, economic theory predicts that the enrollment decision depends solely on the relative net price of the institutions within a student's choice set. However, despite a theoretical rationale for a net price metric, prior research has found a differentiated response across tuition and financial aid that calls for a more complex differentiated price model to study the price response of students (Paulsen, 2001; St. John, 2003). Consistent with the economic predictions and following most prior research our model restricts a dollar increase in grants and scholarships to be equivalent to a one dollar decrease in the price, whereas the less generous forms of aid (loans and work-study) are permitted to yield differential effects as would be expected given the less than dollar-for-dollar impact on the net price (Leslie \& Brinkman, 1987; Heller, 1997).

We use the net price elasticity because it permits us to compare the price responsiveness across groups by normalizing price and enrollment changes into percentage changes. Specifically, the net price measure is normalized by the average price over the period such that a change in the net price variable measures the percentage change in the price. It follows that calculating the marginal effect (delta-p statistic) for the net price variable, as estimated through a probit estimation of equation [1], measures the price elasticity of demand. The estimated net price elasticities across income and ability categories will be used to evaluate how a movement towards a HH or LL model will effect enrollment across the need-ability distribution of UO students.

\section{Control Variables}

In addition to tuition controls, prior institutional demand models include controls for the financial, academic, personal, behavioral, and peer group attributes of applicants (e.g., Curs \& Singell, 2002; DesJardins, Ahlburg, \& McCall, 2006; Ehrenberg \& Sherman, 1984). While our analysis focuses on characteristics of the applicant that have been included in prior work, the elasticity results are robust to a number of alternative sets of controls. For example, dropping any 
of the sets of regressors included in the financial, academic, personal, behavioral, and peer group attributes do not change the qualitative findings with respect to the net price variables. Specifically, although the magnitudes of the coefficients may change with the inclusion and exclusion of the various sets of controls, we find that the coefficient signs and elasticity interpretations remain robust. Further, the results with respect to price constructs are consistent with prior studies which utilize admissions data from the UO (Curs, 2008; Curs \& Singell, 2002; Singell \& Stone, 2002, 2007). Although our estimates are not sensitive to the specification, we use the fully specified model that minimizes the potential for omitted variable bias in interpretation and the simulations.

Academic attributes are measured by the applicant's prior academic performance as indicated by their high school GPA and cumulative SAT score. These academic performance measures may well have differential effects across the ability distribution of students. Specifically, good students are more likely to do well at the UO, but are also likely to have better external opportunities that become more affordable as their parent's income rises.

Personal attributes include a binary variable that equals one if the applicant is female, Asian, African American, or Hispanic. These controls permit the UO enrollment response to differ by race and gender. As the UO is located in a largely white, middle-class, moderately-sized city the institution might well differentially attract students according to their personal attributes.

Behavioral attributes are intended to capture a student's predisposition to attend the UO and include the age the student first contacts the UO and the age the student applies to the UO. In particular, a younger contact age may reflect a relatively greater interest in the UO, whereas age at application may well be inversely correlated with the likelihood of enrollment because the UO is a residential campus that historically enrolls younger students. Our controls for the predisposition to 
attend the UO also include binary variables that equal one if a student is an Arts and Science or Professional major versus the excluded group of applicants with undeclared majors. The controls for major reflect the fact that students may sort non-randomly across schools and colleges.

Peer group academic attributes are measured by the average SAT score in the student’s high school and whether they attended a private high school. The group performance measures provide a relative reference for the applicant's own SAT score. The median household income for the ZIP code of the student's parents is also included to measure the income level of the applicant's peers, which might affect the college aspirations of the student.

\section{Data}

The empirical analysis uses data from the UO admissions office for Fall-term freshman applicants for the academic years 2000-2001 through 2004-2005. The analysis focuses on Fallterm freshman applicants who constitute the majority (96\%) of new applicants and enrollees and who differ distinctly from winter and spring term applicants that are often comprised of nontraditional/transfer students. Overall, our data contain complete information on 34,143 applicants to the UO. More specifically, our data contain 17,810 in-state and 16,333 out-of-state applicants of which $54 \%$ and $21 \%$ enrolled, respectively. Table 1 provides summary statistics for the in-state and out-of-state samples.

\section{Empirical Results}

The Average Enrollment-Price Elasticity for In-state and Out-of-State Students

Following prior work, the enrollment model described in equation [1] is estimated using separate probit specifications for in-state and out-of-state applicants (Curs \& Singell, 2002). Relative to their out-of-state counterparts, Oregonians pay lower tuition at the UO, face a different mix of public and private alternatives within their home state, and are not (at least conceivably) 
selecting from the broad menu of similarly priced flagship public institutions across the United States. Table 1 demonstrates that the average total cost (tuition, fees, room and board) faced by outof-state students is more than double that for in-state students.

Tuition and aid differences by residency status are particularly critical in the context of estimating a net price elasticity of demand. Specifically, because federal, state, and institutional aid tends to rise with the cost of attendance, students who attend college in-state operate in a relatively LL-oriented model and out-of-state students operate in a HH-oriented model. Economic theory predicts and our subsequent empirical analysis confirms that in-state students who face a relatively lower net price have a significantly smaller elasticity of demand than out-of-state students. Moreover, a chi-squared statistic from a likelihood ratio test comparing a model that restricts all coefficients to be the same across residency status versus our proposed models that permits each coefficient to differ with residency status is rejected at the one percent level. Thus, there are sound theoretical and empirical rationales for estimating the probit specifications separately by residency status.

As a point of reference before separating by need and ability, it is useful to estimate the model for all in-state and out-of-state students, which has been the primary approach adopted in prior research estimating the enrollment response to tuition. The results of this specification are presented in Table 2. All coefficients presented in the text and tables are marginal effects calculated at the median value of each independent variable (delta-p statistic), thus, they can be interpreted as the change in the probability of enrollment associated with a one unit change in the independent variable. Similar to prior research results, in-state students are found to have an inelastic net price response with an estimated elasticity of -0.87 and out-of-state students are found to be more responsive than their in-state counterparts with an elasticity estimate of -1.20 . While 
the price responsiveness of the average UO student appears to be relatively low, subsequent results indicate that price elasticity estimates vary substantially with income and ability, indicating that some students are very responsive to changes in the net price.

The empirical relationships with regard to the non-price related controls generally confirm a priori expectations of mixed selectivity effects consistent of a public flagship university with an explicit access mission. For example, for both in-state and out-of-state students, the enrollment probability decreases with both SAT score and high school GPA. Females and non-white students are less likely to attend the UO for both in-state and out-of-state students. Applicants who apply at younger ages and those applying to professional schools are more likely to attend UO, while applicants to the College of Arts and Sciences are less likely to attend UO. With respect to peer group controls, students from areas with lower median household income are more likely to attend the UO and students from private high schools are less likely to attend UO. For brevity, and because the control variables are relatively robust to alternative specifications, the remainder of the discussion focuses on the net price measures that are of primary interest.

\section{The Need-Ability Groupings}

The previous results indicate that the enrollment-price elasticity differs between in-state and out-of-state students. At the same time, access to merit- and need-based aid differs systematically by need and ability, which could well alter students' relative price responsiveness by affecting their relative opportunities. For example, it is likely that students of higher ability or higher need would have higher probabilities of receiving both financial aid from UO and larger financial aid offers from other institutions in their choice set and, thus, may be less responsive to financial aid offers from the UO. Such differences are critical to evaluating how a movement away or towards a $\mathrm{HH}$ 
(or LL) model would impact student choices and, ultimately, the composition of students by need and ability attending the UO.

To examine whether students of differing need and ability respond differently to changes in the UO net price, the enrollment model presented in Table 2 is re-estimated separately for a matrix of 9 need-ability categories, reflecting the implicit or explicit differences in these applicant’s opportunities and costs. The categories are defined along a three-by-three continuum of need and ability, such that students within a group are relatively similar in terms of need and ability and such that the middle category can be though of as the group of students that may or may not qualify for need- or merit-based aid. In other words, the middle categories in the three-by-three need-ability matrix represent the group of otherwise similar students who are most likely to experience changes in both merit- and need-based aid based in response to small changes in their academic and/or financial attributes.

The three need categories (non-needy, somewhat-needy, and needy) delineate a student's ability to pay for college. Non-needy students are those students who do not qualify for Federal need-based aid either because they have not completed a Free Application for Federal Student Aid (FAFSA) or because they have completed a FAFSA and have negative financial eligibility as determined by Federal need-based aid standards. Financial eligibility is calculated as the difference between the cost of attendance (COA) at the UO and the student's expected family contribution (EFC) based on FAFSA information. Students with positive financial eligibility are eligible for Federal need-based aid programs such as the Pell Grant, Supplementary Educational Opportunity Grant, and the subsidized Stafford Loan.

The somewhat-needy category is defined to include students who are eligible for subsidized student loans, but are generally not eligible for the maximum level of Federal grant aid (e.g., Pell 
grants). In other words, somewhat needy students are defined around the margin of receiving the most generous forms of need-based aid, which occurs for approximately two-thirds of the students with positive financial eligibility. Thus, for simplicity, needy and somewhat-needy applicants are defined to yield a one-third versus two-thirds split, respectively, of students who have positive financial eligibility. This split also insures sufficient sample sizes in the needy and somewhat needy categories to obtain precise elasticity estimates.

It is important to emphasize that non-needy out-of-state students generally have a higher level of income than comparable non-needy in-state students with the equivalent eligibility for Federal financial aid because need is determined not only by the student's ability to pay (EFC) but also by the cost of attending (COA) the UO, which is higher for out-of-state students. As out-ofstate tuition exceeds in-state tuition, the range of financial eligibility for somewhat-needy in-state applicants is smaller (\$1-\$8000) than for out-of-state applicants $(\$ 1-\$ 13,000)$. It follows that instate students have lower eligibility ( $>$ \$8000) to qualify as needy in relation to what is required to qualify for out-of-state students (>\$13,000).

The three academic ability categories (less-able, somewhat-able, and able) represent increasing academic performance in high school as measured by high school GPA. In particular, the primary scholarship program at the UO requires a minimum 3.5 high school GPA in order to be eligible for merit aid. Other factors influencing the awarding of merit aid at the UO include the difficulty of their high school curriculum, the year they apply, and the quality of the applicant pool. Thus, the less-able category is defined as those with less than a 3.5 GPA who do not qualify for merit aid. The somewhat-able category is defined such that some, but not all, of the applicants qualify for a merit aid. Specifically, a high school GPA between 3.5 and 3.65 may or may not qualify an applicant for a scholarship, with merit aid decisions for this group being dependent on a 
variety of other factors beyond simply high school GPA. However, able students with a high school GPAs above 3.65 generally qualify for and receive merit aid from the UO.

\section{Enrollment-Price Elasticity Estimates across Need and Ability}

Table 3 presents the estimated net price elasticities for UO in-state and out-of-state freshman applicants estimated using separate probit specifications for the nine need-ability groups. The specifications in Table 3 are identical to those presented in Table 2, however, results for the non-price variables have been excluded for ease of presentation. Thus, the focus is on the variation in the net price elasticity estimates across the nine need-ability groups for in-state and out-of-state students.

The net price results for in-state freshman applicants are presented in a three-by-three matrix on the left-hand side of Table 3 and suggest two systematic patterns of price responsiveness to changes in the UO net price. First, the estimated net price elasticity estimates indicate that price responsiveness falls with ability holding need constant. The decline in price responsiveness across ability is consistent for all three need categories, indicating that students with higher academic abilities are less responsive to price changes when controlling for their financial need and other factors. While the inverse relationship between ability and price responsiveness may appear counter intuitive, it is important to remember that much of the variation in the net price across ability levels arises from variation in aid generally and scholarships in particular. In other words, within a particular year, all students within each residency group face the same tuition price, and the net price varies solely due to differences in financial aid. In this light, the results suggest that responsiveness to aid declines with ability. This is not surprising since opportunities for financial aid at competing institutions are also likely to improve with ability. Thus, given that scholarships are generally not given to persons at the bottom of the ability distribution, the results suggest that 
scholarships are most effective at encouraging applicants to enroll from the middle and bottom of the ability distribution. This result may also suggest that more able students who have access to scholarships across institutions come to expect scholarship support at their ultimate enrollment choice.

Second, the neediest students are the least responsive to changes in net price at the UO controlling for ability. While the neediest group is the least price responsive across all ability categories, price responsiveness does not necessarily decline as need rises for all ability groups. In fact, the difference in the price responsiveness for the non-needy and somewhat-needy groups was generally not statistically significant for the different classes of ability. As the majority of needbased aid is derived from Federal sources and can accompany an applicant to any of the institutions they choose, it is not surprising that needy students are the least responsive to changes in the net price of the UO. For example, if needy applicants receive a larger than expected Pell Grant offer at the UO, they would also receive this increase at any of the other institutions to which they have applied. The perceived drop in price is universal, and has not lowered the UO’s relative price. However, as the financial need level for a student falls, the mix of institutional versus Federal financial aid in their package at the UO is likely to increase such that observed aid increases reflect a real reduction in the price of the UO relative to other institutions. Thus, the price responsiveness of the somewhat- and non-needy student groups are more likely to truly reflect the effectiveness of UO financial aid offers at altering these students' likelihood of attending the UO.

The out-of-state net price enrollment elasticity estimates, presented in columns 4 through 6 of Table 3, indicate that applicants in the middle of the need distribution tend to be the most price responsive. Thus, reductions in the net price through grants and scholarships have the greatest enrollment impact on out-of-state students who are in the middle of the need distribution for UO 
applicants. In other words, students who are in the middle of the need distribution are the marginal students who are most influenced by the provision of aid. Non-needy students tend to be less responsive because higher-cost alternatives to the UO tend to be preferred and these students can more readily afford these options. On the other hand, needy students are less responsive because they tend to be financially constrained such that low-cost public institutions in their own states are generally preferred to more costly out-of-state public institutions.

Alternatively, the price responsiveness of out-of-state applicants to the UO generally decreases as ability levels rise, similar to that of in-state students. Again, this result is consistent with the fact that high ability students are more likely to receive merit-based aid packages across their choice set of schools such that the price discount is not unique to the UO. However, unlike our findings for in-state students, somewhat-able, non-needy applicants from out of state are found to be the least responsive to price. This finding may be indicative of the fact that non-needy students are the least likely to rely on finances as an important factor in the college choice decision. In other words, although somewhat-able students are less likely than able students to receive generous financial aid awards across their choice set of schools, the non-needy among them are less constrained by finances in their choice of institution.

\section{Simulations}

\section{Simulation Format}

Many large public universities attract an academically and demographically similar student body to the UO and have a similar competitive position within the hierarchy of institutions with regard to price and institutional attributes. Thus, the significant differences in the estimated price elasticity across need-ability groups at the UO indicate that tuition and financial aid policy can potentially influence the composition of enrollees by need and ability across a relatively numerous 
set of similarly situated institutions. It follows that we use UO enrollment data for fall term freshman in 2005 and the nine elasticity estimates to simulate the enrollment and institutional net revenue effects of two widely employed tuition and aid policies within higher education. These simulations are broadly applicable only within in the set of comparatively similar institutions to the UO.

As the estimated net price elasticity tells us the estimated percentage change in enrollment with respect to a one percent change in net price, we calculate the simulated enrollment by needability category as the product of the original enrollment, the estimated net price elasticity, and one plus the simulated percentage change in price. Specifically, given the net price elasticity estimates and the assumed change in net price, the percentage change in enrollment can be calculated as:

$$
\% \Delta Q=E_{Q}^{P} * \% \Delta P
$$

Where $\% \Delta Q$ is the percentage change in enrollment, $E_{Q}^{P}$ is the estimated price elasticity of demand presented in Table 3 for each need-ability group, and $\% \Delta P$ is the percentage change in price associated with given tuition policy.

Suppose that a tuition policy was adopted that raised the net price by 5 percent, then the predicted enrollment change could be estimated using the net price elasticity. For example, the predicted percentage enrollment change for the non-needy, less able group of in-state students in the HH model presented in row 2, column 3 of Table 3 is calculated as:

$$
\% \Delta Q=E_{Q}^{P} * \% \Delta P=-3.344 * 5.0 \%=-16.7 \% .
$$

The $-16.7 \%$ figure in [3] is derived using the 5.0 percentage change in the price as presented in row 1, column 3 of Table 4 and the -3.344 net price elasticity presented in row 1, column 1 of Table 3. High-Tuition/High-Aid Simulation 
We first consider a movement towards a HH policy often adopted by selective, largely private, universities. This policy ostensively charges high list tuitions to limit excess enrollment demand and uses the additional revenues to cross subsidize needy (and sometimes relatively able) students with high levels of institutional aid. To simulate a movement towards a HH pricing model at the UO, we first conduct a thought experiment that raises the net price to students who would not qualify for merit- or need-based aid by five percent and then determine what would be the necessary net price reduction offered to needy and able students such that there is no change in the total enrollment of the institution. We keep enrollment constant so that distributional changes can be made in comparison to the same base and the costs or benefits of the HH or LL models are defined solely in terms of revenue. Given that both the net price and the net price elasticity differ by residency status, separate simulations are conducted for in-state and out-of-state students. Thus, the HH simulation results are presented in Tables 4 and 5 for in-state and out-of-state students, respectively.

Needy and able students at UO, both in-state and out-of-state, are found to be less responsive to changes in the net price (i.e., have smaller net price elasticity estimates). Thus, the simulations indicate that the net price charged to needy and able students must decline by more than five percent to offset the enrollment decline of non-aid-eligible students who, by design, have experienced a five percent net price increase. In particular, needy and able in-state (out-of-state) students would need to experience a $10.6(7.0)^{1}$ percent net price decrease in order to ensure that enrollments were unaffected by the adoption of a high tuition, high aid model.

The movement towards a HH policy also affects the composition of the student body. Specifically, the number of needy in-state (out-of-state) enrollees is estimated to increase by 6.0 $(7.9)^{2}$ percent resulting in an overall increase from 33 to 35 (23 to 25) percent of the overall 
incoming freshman class. Similarly, the enrollment of able in-state students is predicted to increase by $9.6(6.4)^{3}$ percent resulting in an overall increase from 45 to 49 (35 to 38) percent of the overall incoming freshman class. Thus, it appears that a targeted aid can effectively be used to increase the enrollment of aid-eligible students.

However, altering the composition of the student body in favor of aid eligible students is costly. Specifically, keeping the need-ability composition of the in-state applicant pools constant, the tuition revenue earned by the institution is predicted to decline by over $\$ 1.14$ million due to the fact that the net price discounts given to aid eligible students exceed the net price induced revenue received from non-aid-eligible students. Similarly, the revenue decline predicted in the simulation for out-of-state students is estimated to be $\$ 228$ thousand from a shift towards a HH model.

It is important to emphasize that the simulation does not account for the fact that a movement towards a HH model might well be expected to favorably influence the applicant pool through an increase in applications from needy and/or able students, which would reduce the negative revenue effects (Curs \& Singell, 2002). These findings highlight the fact that the variation in the price responsiveness across the need-ability distribution (at the UO and other similarlysituated flagship public institutions) will generally make the cross-subsidization of aid-eligible students by non-aid-eligible students impractical and that a $\mathrm{HH}$ model will generally require an infusion of non-tuition related income to fund the policy.

\section{Low-Tuition/Low-Aid Simulation}

A movement towards a LL model, which has been historically adopted by less-selective public universities, typically charges low list tuition to foster access for in-state students (regardless of need or ability) while offering relatively limited institutional need- or merit-based aid. To simulate a movement towards a LL pricing model at the UO, we conduct a second thought 
experiment that eliminates all institutional financial aid, while keeping state- and Federal-based financial aid at their present levels, and estimates the percentage decrease in net-tuition for all students that would result in no change in overall freshman enrollment. Given that both the net price and the net price elasticity differ by residency status, separate simulations are conducted for in-state and out-of-state students. Thus, the simulation results are presented in Tables 6 and 7 for in-state and out-of-state students, respectively.

The elimination of institutional financial aid leads to a $18.0(4.2)^{4}$ percent increase in net price for needy in-state (out-of-state) students. Likewise, the removal of institutional aid leads to a $13.3(12.5)^{5}$ percent net price increase for able in-state (out-of-state) students. The simulations imply that, given the estimated elasticity estimates and in the absence of institutional and statebased financial aid, the list tuition for those in-state (out-of-state) students who are not aid-eligible could be lowered by an average $5.7(4.8)^{6}$ percent in order to keep fall term freshman in-state (outof-state) enrollments constant. The movement towards a LL model can offset the enrollment reduction due to the relatively large increase in the net price (due to the elimination of institutional aid) to aid-eligible students with a relatively small reduction in the net price (which in this case is equivalent to the list price) to non-aid eligible students. The cross-subsidization described is possible because non-aid eligible students are relatively more price responsive at the UO (i.e., they have relatively higher elasticity estimates).

The removal of a targeted aid program that increases the net price for aid-eligible students and reduces the net price to non-aid eligible students will clearly yield a student body with relatively fewer needy and able students. In particular, the simulation predicts that needy, in-state (out-of-state) enrollment would decline by $9.8(0.9)^{7}$ percent, which would result in an overall reduction in the percent of all in-state (out-of-state) students who are needy from 33 to 30 (23.0 to 
22.8) percent. Likewise, the simulation predicts that the enrollment of able in-state and out-of-state students would decline by $10.5(10.7)^{8}$ percent, which reduces their overall share in the incoming class from 45 to 40 (35 to 32) percent for in-state (out-of-state) students.

The movement towards a LL model, although clearly harming an institution's ability to recruit needy and able students, permits the state to provide access to its constituents at a lower overall monetary cost. Specifically, the simulated LL plan would raise average net price revenues from in-state students by $\$ 601$ and from out-of-state students by $\$ 339$. Assuming no change in the composition of the applicant pool, this would result in nearly \$1.0 million in extra tuition revenue without changing the number of in-state students attending and \$220 thousand from out-of-state students. Thus, the LL model clearly trades off the common interest in the recruitment of top students with increasing needs for greater tuition revenues. Such tradeoffs, while perhaps unpalatable to faculty, are made more relevant by the reduction in the state financing of public higher education.

\section{Discussion}

The reduction in state support for higher education and the resulting heightening of competition within public higher education has caused policy pundits and college administrators to contemplate alternative pricing strategies to insure access and improve academic quality. Many public universities have sought to follow their elite private counterparts by moving towards a $\mathrm{HH}$ model to manage their enrollments and generate greater tuition revenue (Turner, 2006). The HH strategy makes economic sense in the context of prior evidence that enrollment demand is inelastic such that tuition revenue can be raised by increasing the net price charged to well-to-do, less meritorious students and using the new revenue to subsidize needy and/or able students. The collective interest in attracting needy and able students within higher education, however, yields 
greater relative opportunities for these students. Such opportunity differences would be expected to make needy and able students relatively less price responsive and limit or even prevent the effective use of the $\mathrm{HH}$ pricing strategy, particularly at less selective public institutions that do not have significant excess enrollment demands.

This paper is the first to examine whether net price responsiveness differs across need and ability for a particular large public institution and to explore the potential enrollment and revenue ramifications of adopting alternative pricing strategies. The net price elasticity estimates for nine need-ability groups indicate that price responsiveness generally declines with both need and ability for both in-state and out-of-state students. The robustness of the price-elasticity variation across need and ability for both in-state and out-of-state students for the University of Oregon is important because it suggests a consistent pattern of price responsiveness at both a relatively low-tuition, lowaid orientation used on in-state (needy) students and for a relatively high-tuition, high-aid orientation used on (able) out-of-state students. Our findings are likely to extend to other public flagship institutions that attract similar students and that tend to follow similar pricing strategies.

We also demonstrate how the elasticity estimates can be used to simulate the enrollment and revenue effects of moving towards an HH or LL pricing strategy. In particular, simulations show that a movement towards a more $\mathrm{HH}$ oriented pricing policy constrained to maintain current enrollment levels will necessarily lower tuition revenue at competitively similar institutions to the UO. This result follows because the aid increases (i.e. net price reductions) necessary to attract a greater number of needy and able students must exceed the net price increases to students who are not eligible for aid. Thus, a movement towards a HH pricing strategy, while raising the predicted representation of needy and able students, requires greater non-tuition revenues (i.e., government or private support) to fund the policy. Thus, these elasticity and revenue findings jointly indicate that 
such institutions could only successfully implement a HH pricing strategy if they are able to reverse the tide of declining government support for higher education or if they are able to overcome their historical limitations for private fundraising. Our findings suggest that similar exercises for relatively selective institutions is an important avenue of future work as these schools likely have applicant pools that exhibit more revenue-favorable variation in their price elasticities and greater external (non-tuition related) funding, which may be the only circumstance when the $\mathrm{HH}$ pricing strategy is feasible.

State disinvestment in higher education has moved flagship public institutions away from their historical LL pricing strategy with low state-subsidized tuition and relatively little institutional aid. Our elasticity estimates are also used to simulate the enrollment and revenue effects of a move back towards a LL pricing strategy. The simulations show that less generous aid packages reduce the relative representation of needy and able students, whereas tuition revenues increase with lower average tuition prices because non-aid-eligible students are relatively price responsive. It follows that a movement towards a LL pricing strategy may be a relatively low-cost means of encouraging students to attend college in their home state. Further research needs to be conducted to understand if the real tuition growth brought about by declining state support can explain the growing proportion of out-of-state students at flagship public institutions.

Overall, the findings from this paper suggests that the effectiveness of any pricing strategy depends on the relative price responsiveness of the targeted versus non-targeted student populations. This is important because there is growing heterogeneity across states and institutions in the types of targeted aid. For example, a number of states have adopted state-based merit aid programs such as the Georgia Hope Scholarship that offer scholarships to Georgia residents who earn at least a B average. At the same time, a growing number of institutions have adopted targeted 
need-based aid programs such as the Carolina Compact at the University of North Carolina that guarantees to meet all unmet need for admitted students. Alternatively, the DC Tuition Assistance program is neither merit or need-based, but provides grants of up to $\$ 10,000$ to cover the difference between in-state and out-of-state tuition for DC residents. The distributional and revenue effects of these hybrid pricing strategies are not well understood and require a more complete picture of difference in the price responsiveness of students both within and across institutions. 


\section{Endnotes}

1. For the HH tuition model, the percentage decrease in price to needy and able students to keep enrollments constant, given a 5 percent increase on all other students, can be found in row 7, column 9 for needy students and row 5, column 12 for able students in Table 4 (5) for instate (out-of-state) students.

2. Row 8, column 9.

3. Row 6, column 12.

4. Row 7, column 9 of Table 6 for instate and Table 7 for out-of-state needy students.

5. Row 5, column 12.

6. Row 1, column 3.

7. Row 8, column 9.

8. Row 6, column 12. 


\section{References}

Abraham, K., \& Clark, M. A. (2006). Financial aid and students' college decisions: Evidence from the District of Columbia Tuition Assistance Grant Program. Journal of Human Resources, 41, 578-610.

Blakemore, A. E., \& Low, S. A. (1983). Scholarship policy and race-sex differences in the demand for higher education. Economic Inquiry, 21, 504-519.

Bennett, W. J. (1987, February 18). Our greedy colleges. The New York Times, p. A31.

Cabrera, A., Burkum, K. R., \& La Nasa, S. (2005). Pathways to a four-year degree: Determinants of transfer and degree completion. In A. Seidman (Ed.), College Student Retention: Formula for Success (pp. 155-214). Westport, Ct: ACE/Praeger Series on Higher Education.

Cabrera, A., \& La Nasa S. (2000). Understanding the college choice process. New Directions for Institutional Research, 107, 5-22.

Campbell, R., \& Siegal, B. (1967). The demand for higher education in the United States 19191964. American Economic Review, 57, 484-494.

Card, D. (1999). The causal effects of education on earnings. In O. Ashenfelter \& D. Card (Eds.), Handbook of labor economics: Vol. 3 (pp. 1801-1863). Amsterdam: Elsevier.

Curs, B. R. (2008). The effect of institutional merit-based aid on enrollment decisions of needy students. Enrollment Management Journal, 2(1), 10-31.

Curs, B., \& Singell, L. D. (2002). An analysis of the application and enrollment process for instate and out-of-state students at a large public university. Economics of Education Review, 21, $111-124$. 
DesJardins, S. L., Ahlburg, D. A., \& McCall, B. P. (2006). An integrated model of application, admission, enrollment, and financial aid. Journal of Higher Education, 77, 381-429.

DesJardins, S. L., \& Bell, A. (2006). Using economic concepts to inform enrollment management. In R. K. Toutkoushian \& M. B. Paulsen (Eds.), New directions for institutional research: No. 132. Applying economics to institutional research. San Francisco: Jossey-Bass.

Doyle, C., \& Cicarelli, J. (1980). The demand for higher education: a disaggregate approach. American Economist, 24, 53-55.

Dynarski, S. M. (2004). The new merit aid. In C. M. Hoxby (Ed.), College Choices: The Economics of Which College, When College, and How to Pay For It. Chicago: The University of Chicago Press, pp. 63-97.

Ehrenberg, R. G., \& Sherman, D. R. (1984). Optimal financial aid policies for a selective university. Journal of Human Resources, 19(2), 203-30.

Epple, D., Romano, R. E., \& Sieg, H. (2002). On the demographic composition of colleges and universities in market equilibrium. American Economic Review, 92, 310-314.

Fuller, W.C., Manski, C.F., \& Wise, D. A. (1982). New evidence on the economic determinants of postsecondary school choice. Journal of Human Resources, 17, 477-498.

Heller, D. E. (1997). Student price response in higher education: An update to Leslie and Brinkman. Journal of Higher Education, 68, 624-659.

Heller, D. E. (2001). Trends in the affordability of public colleges and universities: The contradiction of increasing prices and increasing enrollment. In D. Heller (Ed.), The states and public higher education policy: Affordability, access, and accountability. Baltimore: Johns Hopkins University Press. 
Hossler, D., \& Gallagher, K. S. (1987). Studying student college choice: A three-phase model and the implications for policymakers. College and University, 62, 207-221.

Hossler, D., Braxton, J., \& Coopersmith, G. (1989). Understanding student college choice. In J. C. Smart (ed.), Higher Education: Handbook of Theory and Research. Vol. 5. New York: Agathon Press.

Jackson, G. A. (1978). Financial aid and student enrollment. The Journal of Higher Education, 49(6), 548-574.

Jackson, G. A. (1990). Financial aid, college entry, and affirmative action. American Journal of Education, 98(4), 523-550.

Johnstone, B. (1997). Financing higher education: Who should pay and other issues. In P. Altbach, R.O. Berdahl, \& P. Gumport (Eds.), The American university in the $21^{\text {st }}$ century. Baltimore: Johns Hopkins University Press.

Kane, T. J. (1999). The Price of Admission: Rethinking How Americans Pay for College. Washington DC: Brookings Institutions Press.

King, J. E. (1999). Financing a College Education: How it Works, How It's Changing. Phoenix, AZ: Oryx Press.

Kolpin, V., \& Stater, M. (2006). Greedy colleges? Strategic behavior and the impact of higher education policy (University of Oregon Working Paper). Eugene: University of Oregon, Department of Economics.

Leslie, L. L., \& Brinkman, P. T. (1987). Student price response in higher education: The student demand studies. Journal of Higher Education, 58, 181-204. 
Linsenmeier, D., Rosen, H., \& Rouse, C. (2002). Financial aid policies and college enrollment decisions: An econometric case study. NBER Working Paper \#9228. Cambridge, MA: NBER.

Long, B. T. (2004). How do financial aid policies affect colleges? The institutional impact of the Georgia HOPE Scholarship. Journal of Human Resources, 39, 1045-1066.

Manski, C. F., \& Wise, D. (1983). College Choice in America. Cambridge, MA: Harvard University Press.

McMillen, D. P., Singell, L. D., \& Waddell, G. R. (2007). Spatial competition and the price of college. Economic Inquiry, 45(4), 817-833.

McPherson, M. S., \& Schapiro, M. O. (1991). Does student aid affect college enrollment? New evidence on a persistent controversy. American Economic Review, 81, 309-18.

McPherson, M. S. \& M. O. Schapiro, (1998). The Student Aid Game. Princeton, NJ: Princeton University Press.

Mortenson, T. (1993). The Vermont model of financing higher education. Postsecondary Education Opportunity, 10, 11.

Mumper, M. (2003). Does policy design matter? Comparing universal and targeted approaches to encouraging college participation. Education Policy, 17(1), 38-59.

Parker, F., \& Summers, J. (1993). Tuition and enrollment yield at selective liberal arts colleges. Economics of Education Review, 12, 311-324.

Paulsen, M.B. (1990). College Choice: Understanding Student Enrollment Behavior. ASHE ERIC Higher Education Report No. 6 Washington, DC: The George Washington University, School of Education and Human Development. 
Paulsen, M. B. (2001). The economics of human capital and investment in higher education. In M. B. Paulsen \& J. C. Smart (Eds.) The finance of higher education: Theory, research, policy, and practice. New York: Agathon Press.

Perna, L. W. (2006). Studying college choice: A proposed conceptual model. In J. C. Smart (Ed.), Higher Education: Handbook of theory and research, Vol. XXI (pp. 99-157). Springer.

Rose, D. C., \& Sorensen, R. L. (1992). High tuition, financial aid, and cross-subsidization: Do needy students really benefit? Southern Economic Journal, 59, 66-76.

Rothschild, M., \& White, L. J. (1995). The analytics of the pricing of higher education and other services in which the customers are inputs. Journal of Political Economy, 103, 573-586.

Schorr, L. (1988). Within our reach: Breaking the cycle of disadvantage. New York: Doubleday Dell.

Seneca, J. J., \& Taussig, M. K. (1987). The effects of tuition and financial aid on the enrollment decision at a state university. Research in Higher Education, 26, 337-362.

Singell, L. D., \& Stone, J. A. (2002). The good, the poor, and the wealthy: Who responds most to college financial aid? Bulletin of Economic Research, 54, 393-407.

Singell, L. D., \& Stone, J. A. (2007). For whom the Pell tolls: A test of the Bennett hypothesis. Economics of Education Review, 26(3), 285-295.

St. John, E. P. (1990). Price response in enrollment decisions: An analysis of the high school and beyond sophomore cohort. Research in Higher Education, 31(2), 161-176.

St. John, E.P. (2003). Refinancing the College Dream: Access, Equal Opportunity, and Justice for Taxpayers. Baltimore and London: Johns Hopkins University Press.

Tierney, M. L. (1982). The impact of institutional net price on student demand for public and private higher education. Economics of Education Review, 4, 363-383. 
Turner, S. (1998). Does federal aid affect the price students pay for college? Evidence from the Pell Program. Unpublished manuscript. University of Virginia.

Turner, S. (2006). Higher tuition, higher aid, and the quest to improve opportunities for lowincome students: The case of Virginia. In R. G. Ehrenberg (Ed.), What’s happening to public higher education: The shifting financial burden (pp.251-274). Baltimore: The Johns Hopkins University Press.

Wetzel, J., O'Toole, D., \& Peterson, S. (1998). An analysis of student enrollment demand. Economics of Education Review, 17, 47-54.

Wilson, W. J. (1987). The truly disadvantaged: The inner city, the underclass, and public policy. Chicago: University of Chicago Press 
Table 1: : Summary Statistics

\begin{tabular}{|c|c|c|c|c|}
\hline Panel A: In-State Students (n=17810) & Mean & St. Dev. & Min. & Max \\
\hline Enrolled at UO & 0.54 & 0.50 & 0 & 1 \\
\hline Total Price of UO (Tuition, fees, Room\&Board) ${ }^{1}$ & 13.12 & 1.68 & 10.67 & 16.41 \\
\hline Pell Grant ${ }^{1}$ & 0.17 & 0.45 & 0 & 5.81 \\
\hline Institutional Scholarships ${ }^{1}$ & 1.20 & 1.90 & 0 & 18.07 \\
\hline Loans $^{1}$ & 4.79 & 5.25 & 0 & 42.25 \\
\hline Work-study ${ }^{1}$ & 0.58 & 0.95 & 0 & 4.03 \\
\hline Cumulative SAT ${ }^{2}$ & 11.30 & 1.61 & 4.40 & 16.00 \\
\hline High School GPA & 3.57 & 0.34 & 1.89 & 4.00 \\
\hline Female & 0.58 & 0.49 & 0 & 1 \\
\hline Asian & 0.08 & 0.27 & 0 & 1 \\
\hline African American & 0.02 & 0.13 & 0 & 1 \\
\hline Hispanic & 0.03 & 0.18 & 0 & 1 \\
\hline Age at first contact & 17.33 & 0.67 & 12.17 & 27.38 \\
\hline Age at application & 17.89 & 0.46 & 15.27 & 27.35 \\
\hline Applied to Arts \& Science & 0.30 & 0.46 & 0 & 1 \\
\hline Applied to a professional school & 0.34 & 0.47 & 0 & 1 \\
\hline Median household income ${ }^{1}$ & 46.71 & 12.66 & 14.74 & 128.85 \\
\hline Average SAT Score of applicants high school $^{2}$ & 10.56 & 1.31 & 0 & 13.26 \\
\hline Attended private high school & 0.08 & 0.28 & 0 & 1 \\
\hline Panel B: Out-of-State Students (n=16333) & Mean & St. Dev. & Min. & Max \\
\hline Enrolled at UO & 0.21 & 0.41 & 0 & 1 \\
\hline Gross Price of UO (Tuition, fees, Room/Board) ${ }^{1}$ & 27.86 & 3.09 & 21.95 & 31.95 \\
\hline Pell Grant ${ }^{1}$ & 0.01 & 0.10 & 0 & 1.59 \\
\hline Institutional Scholarships ${ }^{1}$ & 1.88 & 2.67 & 0 & 18.31 \\
\hline Loans $^{1}$ & 7.04 & 11.23 & 0 & 36.97 \\
\hline Work-study $^{1}$ & 0.39 & 0.88 & 0 & 3.13 \\
\hline Cumulative $\mathrm{SAT}^{2}$ & 11.72 & 1.39 & 5.70 & 16.00 \\
\hline High School GPA & 3.47 & 0.37 & 1.80 & 4.00 \\
\hline Female & 0.56 & 0.50 & 0 & 1 \\
\hline Asian & 0.10 & 0.29 & 0 & 1 \\
\hline African American & 0.02 & 0.13 & 0 & 1 \\
\hline Hispanic & 0.04 & 0.19 & 0 & 1 \\
\hline Age at first contact & 17.40 & 0.62 & 12.25 & 27.53 \\
\hline Age at application & 17.80 & 0.45 & 15.03 & 27.91 \\
\hline Applied to Arts \& Science & 0.34 & 0.47 & 0 & 1 \\
\hline Applied to a professional school & 0.29 & 0.45 & 0 & 1 \\
\hline Median household income ${ }^{1}$ & 66.57 & 27.23 & 0 & 200.00 \\
\hline Average SAT Score of applicants high school ${ }^{2}$ & 10.76 & 1.93 & 0 & 15.10 \\
\hline Attended private high school & 0.26 & 0.44 & 0 & 1 \\
\hline
\end{tabular}

${ }^{1}$ All monetary variables measured in 2006 constant dollars and scaled by 1000 .

${ }^{2}$ SAT scores are scaled by 100 . 
Table 2: : Marginal Effects for Probit Model of Enrollment

\begin{tabular}{|c|c|c|}
\hline \multirow[b]{2}{*}{ Independent Variable } & \multicolumn{2}{|c|}{ Enrolled at the University of Oregon } \\
\hline & In-state & Out-of-State \\
\hline \multirow[t]{2}{*}{ Net price } & $-0.8721 * *$ & $-1.1987 * *$ \\
\hline & $(0.0172)$ & $(0.0209)$ \\
\hline \multirow[t]{2}{*}{ Loans } & $0.0082 * *$ & $0.0021 * *$ \\
\hline & $(0.0009)$ & $(0.0003)$ \\
\hline \multirow[t]{2}{*}{ Work-study } & $-0.1435 * *$ & $-0.0734 * *$ \\
\hline & $(0.0056)$ & $(0.0042)$ \\
\hline \multirow[t]{2}{*}{ Cumulative SAT } & $-0.0499 * *$ & $-0.0278 * *$ \\
\hline & $(0.0030)$ & $(0.0022)$ \\
\hline \multirow[t]{2}{*}{ High School GPA } & $-0.2778 * *$ & $-0.2789 * *$ \\
\hline & $(0.0139)$ & $(0.0090)$ \\
\hline \multirow[t]{2}{*}{ Female } & $-0.0567 * *$ & $-0.0148 *$ \\
\hline & $(0.0086)$ & $(0.0060)$ \\
\hline \multirow[t]{2}{*}{ Asian } & $-0.1334 * *$ & $-0.0557 * *$ \\
\hline & $(0.0153)$ & $(0.0075)$ \\
\hline \multirow[t]{2}{*}{ African American } & $-0.2815 * *$ & $-0.0638 * *$ \\
\hline & $(0.0268)$ & $(0.0132)$ \\
\hline \multirow[t]{2}{*}{ Hispanic } & $-0.1957 * *$ & $-0.0576 * *$ \\
\hline & $(0.0213)$ & $(0.0103)$ \\
\hline \multirow[t]{2}{*}{ Age at first contact } & -0.0013 & 0.0049 \\
\hline & $(0.0073)$ & $(0.0060)$ \\
\hline \multirow[t]{2}{*}{ Age at application } & $-0.0609 * *$ & $-0.0328 * *$ \\
\hline & $(0.0106)$ & $(0.0083)$ \\
\hline \multirow[t]{2}{*}{ Applied to Arts \& Science } & $-0.0728 * *$ & -0.0113 \\
\hline & $(0.0100)$ & $(0.0066)$ \\
\hline \multirow[t]{2}{*}{ Applied to a professional school } & $0.0423 * *$ & $0.0355 * *$ \\
\hline & $(0.0096)$ & $(0.0073)$ \\
\hline \multirow[t]{2}{*}{ Median household income } & $-0.0011^{* *}$ & $-0.0006^{* *}$ \\
\hline & $(0.0003)$ & $(0.0001)$ \\
\hline \multirow[t]{2}{*}{ Average SAT Score of applicants high school } & 0.0039 & -0.0027 \\
\hline & $(0.0031)$ & $(0.0014)$ \\
\hline \multirow[t]{2}{*}{ Attended private high school } & $-0.1328 * *$ & $-0.0515 * *$ \\
\hline & $(0.0146)$ & $(0.0060)$ \\
\hline Observations & 17810 & 16333 \\
\hline
\end{tabular}

Standard errors in parentheses. ** significant at 5\%; * significant at $1 \%$. 
Table 3: Net Price Enrollment Elasticity

\begin{tabular}{|c|c|c|c|c|c|c|}
\hline & \multicolumn{3}{|c|}{$\underline{\text { In-State Students }}$} & \multicolumn{3}{|c|}{$\underline{\text { Out-of-State Students }}$} \\
\hline & $\begin{array}{c}\text { Non } \\
\text { Needy }\end{array}$ & $\begin{array}{c}\text { Somewhat } \\
\text { Needy }\end{array}$ & Needy & Non Needy & $\begin{array}{c}\text { Somewhat } \\
\text { Needy }\end{array}$ & Needy \\
\hline \multirow[t]{3}{*}{ Less Able } & $-3.344 * *$ & $-2.749 * *$ & $-0.656 * *$ & $-1.270 * *$ & $-3.307 * *$ & $-1.653 * *$ \\
\hline & $(3800)$ & $(911)$ & (2015) & $(6020)$ & (699) & (1508) \\
\hline & {$[0.500]$} & {$[0.588]$} & {$[0.565]$} & {$[0.190]$} & {$[0.334]$} & {$[0.242]$} \\
\hline \multirow[t]{3}{*}{ Somewhat Able } & -2.257 & $-2.560 * *$ & $-0.520 * *$ & $-0.481 * *$ & $-2.454 * *$ & $-0.821 * *$ \\
\hline & (1395) & (395) & $(810)$ & (1526) & $(252)$ & $(431)$ \\
\hline & {$[0.497]$} & {$[0.611]$} & {$[0.601]$} & {$[0.152]$} & {$[0.308]$} & {$[0.188]$} \\
\hline \multirow[t]{3}{*}{ Able } & $-1.106 * *$ & $-1.116 * *$ & $-0.501 * *$ & $-0.866 * *$ & $-1.358 * *$ & $-0.564 * *$ \\
\hline & $(4458)$ & (1372) & $(2654)$ & (3628) & $(757)$ & (1459) \\
\hline & {$[0.435]$} & {$[0.513]$} & {$[0.507]$} & [0.169] & {$[0.272]$} & {$[0.182]$} \\
\hline \multicolumn{7}{|c|}{$\begin{array}{l}\text { Number of observations is in parentheses and the percent of applicants enrolled is in the square } \\
\text { brackets. For in-state students non-needy are not eligible for federal aid, somewhat-needy } \\
\text { students have eligibility between } \$ 0 \text { and } \$ 8,000 \text {, and needy student have eligibility greater than } \\
\$ 8,000 \text {. For our-of-state students non-needy are not eligible for federal aid, somewhat-needy } \\
\text { students have eligibility between } \$ 0 \text { and } \$ 13,000 \text {, and needy student have eligibility greater than } \\
\$ 13,000 \text {. For both in-state and out-of-state students able have GPAs greater than 3.65, } \\
\text { somewhat-able have GPAs between } 3.5 \text { and 3.65, whereas less-able students have GPAs less } \\
\text { than } 3.5\end{array}$} \\
\hline \multicolumn{7}{|c|}{$*$ significant at $5 \% ; * *$ significant at $1 \%$} \\
\hline
\end{tabular}


Table 4: Simulation of a High-Tuition/High-Aid Policy for In-State Students

Simulation based upon actual University of Oregon in-state enrollment and net price data for Fall-term 2005.

\begin{tabular}{|c|c|c|c|c|c|c|c|c|c|c|c|c|}
\hline & \multicolumn{3}{|c|}{ Non-Needy } & \multicolumn{3}{|c|}{$\underline{\text { Somewhat-Needy }}$} & \multicolumn{3}{|c|}{$\underline{\text { Needy }}$} & \multicolumn{3}{|c|}{$\underline{\text { Group Total }}$} \\
\hline & $\begin{array}{c}2005 \\
\text { Actual }\end{array}$ & $\begin{array}{c}2005 \\
\text { Simulated }\end{array}$ & $\begin{array}{c}\text { Pct. } \\
\text { Change }\end{array}$ & $\begin{array}{c}2005 \\
\text { Actual }\end{array}$ & $\begin{array}{c}2005 \\
\text { Simulated }\end{array}$ & $\begin{array}{c}\text { Pct. } \\
\text { Change }\end{array}$ & $\begin{array}{c}2005 \\
\text { Actual }\end{array}$ & $\begin{array}{c}2005 \\
\text { Simulated }\end{array}$ & $\begin{array}{c}\text { Pct. } \\
\text { Change }\end{array}$ & $\begin{array}{c}2005 \\
\text { Actual } \\
\end{array}$ & $\begin{array}{c}2005 \\
\text { Simulated }\end{array}$ & $\begin{array}{c}\text { Pct. } \\
\text { Change }\end{array}$ \\
\hline \multicolumn{13}{|l|}{ Less-Able } \\
\hline Net Price & $\$ 13,128$ & $\$ 13,784$ & $5.0 \%$ & $\$ 13,054$ & $\$ 13,707$ & $5.0 \%$ & $\$ 9,086$ & $\$ 8,123$ & $-10.6 \%$ & $\$ 11,868$ & $\$ 11,717$ & $-1.3 \%$ \\
\hline Enrollees & 375 & 312 & $-16.7 \%$ & 92 & 79 & $-13.7 \%$ & 209 & 224 & $7.0 \%$ & 676 & 615 & $-9.0 \%$ \\
\hline \multicolumn{13}{|c|}{ Somewhat-Able } \\
\hline Net Price & $\$ 13,045$ & $\$ 13,697$ & $5.0 \%$ & $\$ 12,669$ & $\$ 13,302$ & $5.0 \%$ & $\$ 8,281$ & $\$ 7,403$ & $-10.6 \%$ & $\$ 11,113$ & $\$ 10,892$ & $-2.0 \%$ \\
\hline Enrollees & 127 & 113 & $-11.3 \%$ & 37 & 32 & $-12.8 \%$ & 107 & 113 & $5.5 \%$ & 271 & 258 & $-4.9 \%$ \\
\hline \multicolumn{13}{|l|}{$\underline{\text { Able }}$} \\
\hline Net Price & $\$ 11,541$ & $\$ 10,318$ & $-10.6 \%$ & $\$ 11,158$ & $\$ 9,975$ & $-10.6 \%$ & $\$ 7,992$ & $\$ 7,145$ & $-10.6 \%$ & $\$ 10,315$ & $\$ 9,262$ & $-10.2 \%$ \\
\hline Enrollees & 404 & 451 & $11.7 \%$ & 110 & 123 & $11.8 \%$ & 253 & 266 & $5.3 \%$ & 767 & 841 & $9.6 \%$ \\
\hline \multicolumn{13}{|l|}{ Group Total } \\
\hline Net Price & $\$ 12,409$ & $\$ 11,988$ & $-3.4 \%$ & $\$ 12,122$ & $\$ 11,695$ & $-3.5 \%$ & $\$ 8,448$ & $\$ 7,556$ & $-10.6 \%$ & $\$ 11,054$ & $\$ 10,389$ & $-6.0 \%$ \\
\hline Enrollees & 906 & 876 & $-3.3 \%$ & 239 & 235 & $-1.8 \%$ & 569 & 603 & $6.0 \%$ & 1714 & 1714 & $0.0 \%$ \\
\hline
\end{tabular}


Table 5: Simulation of a High-Tuition/High-Aid Policy for Out-of-State Students

Simulation based upon actual University of Oregon out-of-state enrollment and net price data for Fall-term 2005.

\begin{tabular}{|c|c|c|c|c|c|c|c|c|c|c|c|c|}
\hline & \multicolumn{3}{|c|}{ Non-Needy } & \multicolumn{3}{|c|}{$\underline{\text { Somewhat-Needy }}$} & \multicolumn{3}{|c|}{$\underline{\text { Needy }}$} & \multicolumn{3}{|c|}{$\underline{\text { Group Total }}$} \\
\hline & $\begin{array}{c}2005 \\
\text { Actual }\end{array}$ & $\begin{array}{c}2005 \\
\text { Simulated } \\
\end{array}$ & $\begin{array}{c}\text { Pct. } \\
\text { Change }\end{array}$ & $\begin{array}{c}2005 \\
\text { Actual }\end{array}$ & $\begin{array}{c}2005 \\
\text { Simulated }\end{array}$ & $\begin{array}{c}\text { Pct. } \\
\text { Change }\end{array}$ & $\begin{array}{c}2005 \\
\text { Actual }\end{array}$ & $\begin{array}{c}2005 \\
\text { Simulated }\end{array}$ & $\begin{array}{c}\text { Pct. } \\
\text { Change }\end{array}$ & $\begin{array}{c}2005 \\
\text { Actual }\end{array}$ & $\begin{array}{c}2005 \\
\text { Simulated }\end{array}$ & $\begin{array}{c}\text { Pct. } \\
\text { Change }\end{array}$ \\
\hline \multicolumn{13}{|l|}{$\underline{\text { Less-Able }}$} \\
\hline Net Price & $\$ 25,560$ & $\$ 26,838$ & $5.0 \%$ & $\$ 25,310$ & $\$ 26,576$ & $5.0 \%$ & $\$ 23,686$ & $\$ 21,981$ & $-7.2 \%$ & $\$ 25,151$ & $\$ 25,668$ & $2.1 \%$ \\
\hline Enrollees & 242 & 227 & $-6.4 \%$ & 42 & 35 & $-16.5 \%$ & 72 & 81 & $11.9 \%$ & 356 & 342 & $-3.9 \%$ \\
\hline \multicolumn{13}{|c|}{$\underline{\text { Somewhat-Able }}$} \\
\hline Net Price & $\$ 24,315$ & $\$ 25,531$ & $5.0 \%$ & $\$ 24,742$ & $\$ 25,979$ & $5.0 \%$ & $\$ 23,754$ & $\$ 22,044$ & $-7.2 \%$ & $\$ 24,254$ & $\$ 24,776$ & $2.2 \%$ \\
\hline Enrollees & 51 & 50 & $-2.4 \%$ & 11 & 10 & $-12.3 \%$ & 17 & 18 & $5.9 \%$ & 79 & 77 & $-2.0 \%$ \\
\hline \multicolumn{13}{|l|}{$\underline{\text { Able }}$} \\
\hline Net Price & $\$ 21,826$ & $\$ 20,255$ & $-7.2 \%$ & $\$ 21,947$ & $\$ 20,367$ & $-7.2 \%$ & $\$ 19,924$ & $\$ 18,489$ & $-7.2 \%$ & $\$ 21,324$ & $\$ 19,800$ & $-7.1 \%$ \\
\hline Enrollees & 122 & 130 & $6.2 \%$ & 50 & 55 & $9.8 \%$ & 66 & 69 & $4.1 \%$ & 238 & 253 & $6.4 \%$ \\
\hline \multicolumn{13}{|l|}{ Group Total } \\
\hline Net Price & $\$ 24,309$ & $\$ 24,576$ & $1.1 \%$ & $\$ 23,617$ & $\$ 23,096$ & $-2.2 \%$ & $\$ 22,092$ & $\$ 20,554$ & $-7.0 \%$ & $\$ 23,693$ & $\$ 23,357$ & $-1.4 \%$ \\
\hline Enrollees & 415 & 406 & $-2.2 \%$ & 103 & 100 & $-3.3 \%$ & 155 & 167 & $7.9 \%$ & 673 & 673 & $0.0 \%$ \\
\hline
\end{tabular}


Table 6: Simulation of a Low-Tuition/Low-Aid Policy for In-State Students

Simulation based upon actual University of Oregon in-state enrollment and net price data for Fall-term 2005.

\begin{tabular}{|c|c|c|c|c|c|c|c|c|c|c|c|c|}
\hline & \multicolumn{3}{|c|}{$\underline{\text { Non-Needy }}$} & \multicolumn{3}{|c|}{$\underline{\text { Somewhat-Needy }}$} & \multicolumn{3}{|c|}{$\underline{\text { Needy }}$} & \multicolumn{3}{|c|}{$\underline{\text { Group Total }}$} \\
\hline & $\begin{array}{c}2005 \\
\text { Actual }\end{array}$ & $\begin{array}{c}2005 \\
\text { Simulated }\end{array}$ & $\begin{array}{c}\text { Pct. } \\
\text { Change }\end{array}$ & $\begin{array}{c}2005 \\
\text { Actual }\end{array}$ & $\begin{array}{c}2005 \\
\text { Simulated }\end{array}$ & $\begin{array}{c}\text { Pct. } \\
\text { Change }\end{array}$ & $\begin{array}{c}2005 \\
\text { Actual } \\
\end{array}$ & $\begin{array}{c}2005 \\
\text { Simulated }\end{array}$ & $\begin{array}{c}\text { Pct. } \\
\text { Change }\end{array}$ & $\begin{array}{c}2005 \\
\text { Actual }\end{array}$ & $\begin{array}{c}2005 \\
\text { Simulated }\end{array}$ & $\begin{array}{c}\text { Pct. } \\
\text { Change }\end{array}$ \\
\hline \multicolumn{13}{|l|}{ Less-Able } \\
\hline Net Price & $\$ 13,128$ & $\$ 12,377$ & $-5.7 \%$ & $\$ 13,054$ & $\$ 12,377$ & $-5.2 \%$ & $\$ 9,086$ & $\$ 9,788$ & $7.7 \%$ & $\$ 11,868$ & $\$ 11,692$ & $-1.5 \%$ \\
\hline Enrollees & 375 & 447 & $19.1 \%$ & 92 & 105 & $14.3 \%$ & 209 & 198 & $-5.1 \%$ & 676 & 750 & $11.0 \%$ \\
\hline \multicolumn{13}{|c|}{$\underline{\text { Somewhat-Able }}$} \\
\hline Net Price & $\$ 13,045$ & $\$ 12,377$ & $-5.1 \%$ & $\$ 12,669$ & $\$ 12,377$ & $-2.3 \%$ & $\$ 8,281$ & $\$ 9,812$ & $18.5 \%$ & $\$ 11,113$ & $\$ 11,483$ & $3.3 \%$ \\
\hline Enrollees & 127 & 142 & $11.6 \%$ & 37 & 39 & $5.9 \%$ & 107 & 97 & $-9.6 \%$ & 271 & 278 & $2.4 \%$ \\
\hline \multicolumn{13}{|l|}{ Able } \\
\hline Net Price & $\$ 11,541$ & $\$ 12,377$ & $7.2 \%$ & $\$ 11,158$ & $\$ 12,377$ & $10.9 \%$ & $\$ 7,992$ & $\$ 10,195$ & $27.6 \%$ & $\$ 10,315$ & $\$ 11,684$ & $13.3 \%$ \\
\hline Enrollees & 404 & 372 & $-8.0 \%$ & 110 & 97 & $-12.2 \%$ & 253 & 218 & $-13.8 \%$ & 767 & 686 & $-10.5 \%$ \\
\hline \multicolumn{13}{|l|}{ Group Total } \\
\hline Net Price & $\$ 12,409$ & $\$ 12,377$ & $-0.3 \%$ & $\$ 12,122$ & $\$ 12,377$ & $2.1 \%$ & $\$ 8,448$ & $\$ 9,966$ & $18.0 \%$ & $\$ 11,054$ & $\$ 11,655$ & $5.4 \%$ \\
\hline Enrollees & 906 & 960 & $6.0 \%$ & 239 & 241 & $0.8 \%$ & 569 & 513 & $-9.8 \%$ & 1714 & 1714 & $0.0 \%$ \\
\hline
\end{tabular}


Table 7: Simulation of a Low-Tuition/Low-Aid Policy for Out-of-State Students

Simulation based upon actual University of Oregon out-of-state enrollment and net price data for Fall-term 2005.

\begin{tabular}{|c|c|c|c|c|c|c|c|c|c|c|c|c|}
\hline & \multicolumn{3}{|c|}{$\underline{\text { Non-Needy }}$} & \multicolumn{3}{|c|}{$\underline{\text { Somewhat-Needy }}$} & \multicolumn{3}{|c|}{$\underline{\text { Needy }}$} & \multicolumn{3}{|c|}{$\underline{\text { Group Total }}$} \\
\hline & $\begin{array}{c}2005 \\
\text { Actual }\end{array}$ & $\begin{array}{c}2005 \\
\text { Simulated } \\
\end{array}$ & $\begin{array}{c}\text { Pct. } \\
\text { Change }\end{array}$ & $\begin{array}{c}2005 \\
\text { Actual }\end{array}$ & $\begin{array}{c}2005 \\
\text { Simulated } \\
\end{array}$ & $\begin{array}{c}\text { Pct. } \\
\text { Change }\end{array}$ & $\begin{array}{c}2005 \\
\text { Actual }\end{array}$ & $\begin{array}{c}2005 \\
\text { Simulated } \\
\end{array}$ & $\begin{array}{c}\text { Pct. } \\
\text { Change }\end{array}$ & $\begin{array}{c}2005 \\
\text { Actual }\end{array}$ & $\begin{array}{c}2005 \\
\text { Simulated } \\
\end{array}$ & $\begin{array}{c}\text { Pct. } \\
\text { Change }\end{array}$ \\
\hline \multicolumn{13}{|l|}{ Less-Able } \\
\hline Net Price & $\$ 25,560$ & $\$ 24,333$ & $-4.8 \%$ & $\$ 25,310$ & $\$ 24,333$ & $-3.9 \%$ & $\$ 23,686$ & $\$ 22,793$ & $-3.8 \%$ & $\$ 25,151$ & $\$ 24,024$ & $-4.5 \%$ \\
\hline Enrollees & 242 & 257 & $6.1 \%$ & 42 & 47 & $12.8 \%$ & 72 & 76 & $6.2 \%$ & 356 & 381 & $6.9 \%$ \\
\hline \multicolumn{13}{|c|}{$\underline{\text { Somewhat-Able }}$} \\
\hline Enrollees & 51 & 51 & $0.0 \%$ & 11 & 11 & $4.1 \%$ & 17 & 17 & $0.6 \%$ & 79 & 80 & $0.7 \%$ \\
\hline \multicolumn{13}{|l|}{ Able } \\
\hline Net Price & $\$ 21,826$ & $\$ 24,333$ & $11.5 \%$ & $\$ 21,947$ & $\$ 24,333$ & $10.9 \%$ & $\$ 19,924$ & $\$ 23,130$ & $16.1 \%$ & $\$ 21,324$ & $\$ 23,993$ & $12.5 \%$ \\
\hline Enrollees & 122 & 110 & $-9.9 \%$ & 50 & 43 & $-14.8 \%$ & 66 & 60 & $-9.1 \%$ & 238 & 212 & $-10.7 \%$ \\
\hline \multicolumn{13}{|l|}{ Group Total } \\
\hline Net Price & $\$ 24,309$ & $\$ 24,333$ & $0.1 \%$ & $\$ 23,617$ & $\$ 24,333$ & $3.0 \%$ & $\$ 22,092$ & $\$ 23,014$ & $4.2 \%$ & $\$ 23,693$ & $\$ 24,032$ & $1.4 \%$ \\
\hline Enrollees & 415 & 418 & $0.6 \%$ & 103 & 101 & $-1.5 \%$ & 155 & 154 & $-0.9 \%$ & 673 & 673 & $-0.1 \%$ \\
\hline
\end{tabular}

